\title{
ОСОБЛИВОСТІ РОЗВИТКУ ПРОФЕСІЙНО ВАЖЛИВИХ ПСИХОЛОГІЧНИХ ЯКОСТЕЙ МАЙБУТНІХ МЕДИЧНИХ СЕСТЕР
}

\author{
Л. В. Задирака \\ Ватутінська філія Черкаського медичного коледжу \\ ДВНЗ «Тернопільський державний медичний університет \\ імені І. Я. Горбачевського МОЗ Украӥни»
}

У статті наведено психолого-педагогічні чинники впливу на професійну та особистісну підготовку майбутніх медичних сестер і надано методичні рекомендації, спрямовані на розвиток їх професійно важливих психологічних якостей.

\section{FEATURES OF DEVELOPMENT OF PROFESSIONALLY IMPORTANT PSYCHOLOGICAL QUALITIES OF FUTURE NURSES}

\author{
L. V. Zadyraka \\ The Filial of Cherkasy Medical College in Vatutine, \\ I. Horbachevsky Ternopil State Medical University
}

The article adduces the pedagogical and psychological factors that influence the professional and personal training of future nurses and provides guidance towards the development of professionally important psychological qualities.

Вступ. У загальній системі медичної освіти особливо багато важить морально-етична підготовка і виховання майбутніх медиків на принципах професійної честі, гуманізму, людської порядності й відповідальності. Духовне зростання, збагачення професійно-моральної та особистісної культури медика - необхідні умови виконання професійного і гуманного обов'язків.

Концептуальні основи формування професійно-моральної та особистісної культури майбутніх медичних сестер спрямовані на забезпечення особистісного розвитку в процесі професійної підготовки через засвоєння студентом цінностей, закладених у професійному і духовному досвіді діяльності в галузі охорони здоров'я та розвитку медицини як науки; об'єднання всіх компонентів процесу формування професійноетичної культури в єдину цілеспрямовану систему професійної підготовки і виховання майбутніх медиків. Зростання ролі середнього медичного персоналу в системі охорони здоров'я зумовлює необхідність підтримки й удосконалення медичними працівниками своїх знань та навичок, докладання необхідних зусиль до професійного самовдосконалення на рівні сучасного стану медицини.

(с) Л. В. Задирака, 2016
Основна частина. Орієнтація суб'єкта на особистісно-професійний розвиток ставить завдання щодо створення умов, спрямованих на активізацію самопізнання і самореалізацію, зміни ставлення особистості до власних досягнень. Іншими словами, перехід від пасивно-споглядальної позиції щодо себе і реальності до активнодіючої [2]. Якщо розглядати компетентність глобально, на перший план виступає результативний аспект як сукупність досягнень у професійній діяльності. Вивчення теоретичних аспектів формування професійної компетентності студентів в умовах медичного закладу дозволило спроектувати модель професійної компетентності медичної сестри, що включає: принципи, компоненти, показники, рівні сформованості, педагогічні умови, орієнтовані на реалізацію принципів терапевтичної спільноти у навчально-виховному процесі. Враховуючи різноманіття виконуваних медичною сестрою функцій і збільшення відповідальності, медичні освітні установи намагаються забезпечити якісну підготовку фахівців на основі позицій взаємодії усіх учасників даного діяльнісного процесу [8]. При цьому будь-яка діяльність повинна бути направлена на формування професійної компетентності майбутнього фахівця 
- медичного працівника і на розвиток особистісної сфери особистості на основі професійно сформованої мотивації і задоволеності навчальною діяльністю вже в стінах навчального закладу. Рівень компетентності $\epsilon$ рівнем діяльності, необхідним і достатнім для мінімальної успішності в досягненні результату [3].

Дуже важливо, щоб у процесі навчання в навчальному закладі прищеплювали такі якості, як співробітництво, самостійність і прагнення до самореалізації при вирішенні професійно орієнтованих завдань. Якщо робота всіх учасників процесу творча, професійна, то в досягненні поставленої мети й успіху можна не сумніватися [1]. У даний час основне завдання будь-якого навчального закладу - не стільки передати знання студентам, скільки навчити самостійно опрацьовувати матеріал, направити студента на самонавчання, саморозвиток і самореалізацію у своїй професійній діяльності.

Професійна підготовка фахівців у медичних коледжах - це динамічне складне педагогічне явище, яке здійснюється на основі цілеспрямованого, організованого, науково обґрунтованого формування особистості майбутнього медика. Ії̈ мета і завдання визначаються суспільними потребами і вимогами до галузі охорони здоров'я, а також розвитком медичної науки.

Як і для формування будь-якої іншої структури особистості, для професійної самосвідомості існують свої сенситивні періоди. Одним із перших значущих періодів $\epsilon$ саме навчання у ВНЗ. У цей час майбутня медична сестра засвоює категоріально-понятійний апарат своєї науки й здобуває необхідні знання й уміння, що дозволяють студентові усвідомлювати свою належність до професійного співтовариства, але їх ефективне використання у професійній діяльності неможливе без сформованої професійної самосвідомості.

Виділяють такі функціональні й структурні компоненти професійної самосвідомості медичної сестри: когнітивний, що реалізується в самопізнанні; мотиваційний, що реалізується в самоактуалізації; емоційний, що реалізується в саморозумінні; операційний, що реалізується в саморегуляції. Розглянемо кожний із цих компонентів більш детально.

Когнітивний компонент самопізнання $\epsilon$ основою самосвідомості. В процесі самопізнання, перетворюючи психічну діяльність на дослідження самої себе, медична сестра свідомо оцінює свої вчинки і себе в цілому. Виявлення особливостей процесу самопізнан- ня повинно розкрити механізм одержання і розвитку медичною сестрою знань про себе. В процесі самопізнання одиничні ситуативні образи формуються в поняття, що відбивають сутність медичної сестри, у якій і виражається ступінь її суспільної цінності. А співвіднесення знання про себе із соціальними вимогами й нормами дає їй можливість визначити своє місце в системі суспільних відносин.

У процесі взаємодії із зовнішнім світом медична сестра виступає активно діючим суб'єктом, пізнає світ, а разом із тим пізнає й себе. Якщо будь-яка річ, явище можуть бути пізнані через співвідношення 3 іншими речами або явищами, через процес виявлення їхніх численних взаємозв'язків, то й самопізнання медичної сестри може здійснюватися лише через його ставлення до інших людей, через різноманітні форми зв'язку їі «я» з «Я» інших. Уявлення індивіда про себе, здебільшого, здаються їй переконливими незалежно від того, чи ґрунтуються вони на об'єктивному знанні або об'єктивній думці, чи вони є суб'єктивними або помилковими. Певні способи самосприйняття призводять до формування образу «я»і, відповідно, «Я-професіонала».

Умовою самосвідомості $є$ перевтілення у себе (сформувати себе як особистість), залишитися самим собою (незважаючи на негативні впливи) і вміти підтримати себе у важкій ситуації, при цьому розуміючи самого себе. Саморозуміння дозволяє розширити уявлення про природу власного «я». Отже, саморозуміння $\epsilon$ необхідною умовою самосвідомості. Саморозуміння, в свою чергу, $є$ проявом емоційного компонента (Т. Кудрявцев). Становлення й розвиток саморозуміння як процесу й результату невід'ємно від розвитку медичної сестри в цілому й залежить від специфічного способу життєдіяльності. Разом з тим саморозуміння $\epsilon$ внутрішньою умовою, яка визначає розвиток медичної сестри й формування індивідуально-типологічних особливостей їі структури. Важливо розуміти себе і бути зацікавленим у дослідженні себе. В такому випадку приходить розуміння того, що «я»- це «я».

Процес саморозуміння зумовлюється зміною уявлень про себе, за допомогою формування проблем, завдань і їхнього рішення відбувається співвіднесення нового знання з якоюсь системою цінностей, формування життєвих, професійних завдань і завдань на визначення своїх можливостей.

Зміст мотиваційно-цільового компонента реалізується через самоактуалізацію. Актуалізуватися означає, стати реальним, існувати фактично, а не 
тільки потенційно. Спираючись на К. Роджерса ми вважаємо, що медична сестра має вроджену тенденцію до самоактуалізації й прагнення до неї проявляється в цілеспрямованому задоволенні потреби в самоактуалізації в її життєвій реальності.

Самоактуалізація припускає реалізацію особистісного потенціалу й удосконалення медичної сестри як професіонала і як особистості. Важливим аспектом самоактуалізації $є$ прийняття відповідальності за свої дії. Самоактуалізація - це постійний процес розвитку своїх потенційних можливостей з метою досягнення творчої зрілості. Професійна самоактуалізація виступає операційним аналогом особистісної зрілості. Високий рівень самоактуалізації сприяє досягненню творчої зрілості особистості. Самоактуалізація $\epsilon$ процесом постійного розвитку й практичної реалізації своїх можливостей (А. Маслоу, К. Роджерса, Ф. Перлза, Е. Шострома, Л. Гозмана) [5].

Самоактуалізація включає процес самовизначення. Медичній сестрі насамперед необхідно самостійно визначити свій професійний розвиток. На всіх етапах навчання професійне самовизначення медичної сестри здійснюється за допомогою процесу самоаналізу поведінки, психологічних властивостей особистості, свідомої постановки питань професійного розвитку, кар'єрного зростання в майбутній професійній діяльності тощо.

Складовою операційного компонента є саморегуляція, яку ми розуміємо як розкриття резервних можливостей психолога, а отже, розвиток його творчого потенціалу. Застосування прийомів саморегуляції припускає активну вольову участь і, як наслідок, єумовою формування сильної, відповідальної особистості. У ході дослідження психічної активності медичної сестри можна виділити дві форми регуляції: спонукальну й виконавчу (С. Рубінштейн) [6]. Спонукальна реакція медичної сестри пов'язана з формуванням професійних прагнень, вибором спрямованості, активності; виконавча - із забезпеченням відповідності активності об'єктивним умовам.

В основі процесу формування професійної ідентичності лежать прагнення до особистісного зростання та самоактуалізації, чітка система ціннісних орієнтацій, високий рівень особистісної зрілості, а також формування професійної свідомості й професійного мислення.

Професіоналізм діяльності характеризується гармонійним поєднанням високої професійної компетентності та професійних умінь і навичок на рівні професійної майстерності. У ході засвоєння професійної діяльності по мірі переходу на більш високі рівні професіоналізму настає етап стабільного використання накопичених у професійному досвіді способів і засобів виконання завдань на рівні високих зразків, що стає основою розвитку професійної майстерності, для досягнення якого необхідно володіти певним особистісним потенціалом. Це - загальні та спеціальні здібності, базові знання, мотивація досягнень, спрямованість на саморозвиток, адекватна самооцінка та професійна компетентність.

Найбільш ефективним шляхом формування професійно-особистісних якостей виступають активні методи навчання, які спрямовані на становлення професійно значущих новоутворень ідентичності майбутньої медсестри.

Застосування соціально-психологічного тренінгу стимулює особистісний розвиток майбутніх медсестер як у системі міжперсональних стосунків, так і у внутрішньоособистісному аспекті, спрямовуючи саморефлексію та особистісну самоорганізацію через пізнавальну активність на становлення професійної ідентичності. Під час тренінгу можна не тільки розвивати певні особистісні якості, але й розв'язувати поставлені діагностичні, корекційні та терапевтичні завдання. Важливим механізмом тренінгу є особистісне змінювання, яке має індивідуальну динаміку прояву, поєднуючи в собі переходи на вищі стадії розвитку через подолання криз, конструювання нових когнітивних концепцій тощо.

Освітньо-кваліфікаційна характеристика випускника вищого медичного навчального закладу узагальнює зміст освіти, відображає цілі освітньої та професійної підготовки, визначає місце фахівця в структурі системи охорони здоров'я і вимоги до його професійної компетентності.

До професійних якостей медичної сестри, що висуваються в професіограмі належать уважність, чуйність, приязність, терплячість та співчуття, володіння комунікативними якостями, які забезпечують ефективну взаємодію з хворими. В нашому дослідженні встановлено, що до психологічних чинників впливу на професійне становлення майбутніх медичних сестер можна віднести «індекс емпатійності», мотиви престижу, професійні мотиви та навчально-пізнавальні мотиви, рівень емпатійності, рівень прояву комунікативних, соціальних та мотивів уникнення.

В навчально-виховному процесі, спрямованому на підготовку майбутніх медичних сестер, для розвитку вказаних у професіограмі психологічних якостей 
варто спрямовувати педагогічний процес на підвищення комунікативної толерантності, емпатії, сприяти творчій самореалізації студентів.

3 цією метою в медсестринській освіті варто формувати серед студентів пізнавальні мотиви. Під час організації роботи потрібно пам'ятати про основну роль викладача в формуванні мотивації студентів, зокрема, його професіоналізм, об'єктивність та справедливість.

Одна з необхідних умов для створення у студентів інтересу до змісту навчання - це можливість проявляти в навчанні розумову самостійність та ініціативу. Цьому сприяє використання завдань, вирішення яких вимагає від студентів активної пошукової діяльності.

Важливо, щоб у процесі навчання в навчальному закладі прищеплювалися такі якості, як співробітництво, самостійність і прагнення до самореалізації при вирішенні професійно орієнтованих завдань.

Висновки. Підбиваючи підсумок, можна сказати, що зміни, які відбуваються в суспільстві і визначили необхідність розробки нової стратегії в підготовці медичних кадрів - формування професійно компетентного фахівця, здатного вирішувати завдання 3 розвитку галузі на основі принципів співробітництва, науковості, раціонального використання наявних ресурсів, технічного вдосконалення, розвитку та реалізації власного потенціалу, становлення осо-

\section{ЛITEPATУРA}

1. Васильева Л. А. Особенности формирования профессиональной компетентности будущих медицинских работников среднего звена / Л. А. Васильева // Вестник ОГУ. - 2011. - № 4. - С. 19-22.

2. Земцова В. И. О принципах и закономерностях адаптации студентов к профессиональной деятельности / В. И. Земцова // Вестник Оренбургского государственного университета. - 2000. - № 1. - С. 11-15.

3. Пометун О. І. Теорія та практика послідовної реалізації компетентнісного підходу в досвіді зарубіжних країн / О. І. Пометун // Компетентнісний підхід у сучасній освіті : світовий досвід та українські перспективи : Бібліотека 3 освітньої політики ; [за заг. ред. О. В. Овчарук]. - К. : К.І.С., 2004. - 112 c. бистісних цінностей. Виходячи з вищевикладеного, можна стверджувати, що основоположним чинником професійної медичної освіти стає розвиток особистісної галузі, а метою - формування професійної компетентності. Успішному становленню професійної компетентності студентів медичних закладів у процесі навчання сприяє усвідомлення і, головне, розвиток основних якостей особистості, якими повинен володіти кожен медичний працівник, при цьому величезне значення в його практичній діяльності має орієнтація на іншу людину як рівноправного учасника діяльнісного процесу.

Для формування професійної компетентності студента медичного закладу - майбутньої медичної сестри необхідні: володіння принципами взаємної співпраці, поєднання професійних якостей і особистісних позицій, прагнення до саморозвитку та самореалізації у своїй майбутній професійній діяльності. Тільки творчий настрій, жага знань і постійний пошук сприяють формуванню професійної компетентності студента-медика, майбутнього фахівця, професіонала своєї справи. Саме вони пробуджують у нього справжню свідомість і творчу активність, прагнення до саморозвитку та самореалізації, саме ці якості настільки необхідні для сучасного фахівця-професіонала своєї справи.

4. Попіль М. І. Психологічні особливості становлення професійної ідентичності майбутніх медсестер : дис. ... канд. психол. наук : 19.00.07 / М. І. Попіль. - Дрогобич, 2009. - 196 c.

5. Роджерс К. Взгляд на психотерапию. Становление человека ; пер. с англ. / К. Роджерс. - 2-е изд. - М. : Московский психолого-социальный институт : Флинта, 2004. -480 c.

6. Рубинштейн С. Л. Основы общей психологии / С. л. Рубинштейн. - СПб. : Питер, 2013. - 720 с.

7. Самоукина Н. В. Психология профессиональной деятельности / Н. В. Самоукина. - СПб. : Питер, 2003. - 224 с.

8. Стрельникова А. Н. Зачем медсестре самооценка / А. Н. Стрельникова // Медсестра. - 2000. - № 1. - С. 42-43. 